\title{
Topical hypochlorite ameliorates NF-kB-mediated skin diseases in mice
}

\author{
Thomas H. Leung, ${ }^{1,2}$ Lillian F. Zhang, ${ }^{1}$ Jing Wang, ${ }^{1}$ Shoucheng Ning, ${ }^{3}$ \\ Susan J. Knox, ${ }^{3}$ and Seung K. Kim ${ }^{1,4,5}$
}

\begin{abstract}
1Department of Developmental Biology, ${ }^{2}$ Department of Dermatology, ${ }^{3}$ Department of Radiation Oncology, ${ }^{4}$ Howard Hughes Medical Institute, and ${ }^{5}$ Department of Medicine, Oncology Division, Stanford University School of Medicine, Stanford, California, USA.
\end{abstract}

\begin{abstract}
Nuclear factor- $\kappa B(N F-\kappa B)$ regulates cellular responses to inflammation and aging, and alterations in NF- $\mathrm{B}$ signaling underlie the pathogenesis of multiple human diseases. Effective clinical therapeutics targeting this pathway remain unavailable. In primary human keratinocytes, we found that hypochlorite $(\mathrm{HOCl})$ reversibly inhibited the expression of $C C L 2$ and $S O D 2$, two NF- $\kappa \mathrm{B}$-dependent genes. In cultured cells, $\mathrm{HOCl}$ inhibited the activity of inhibitor of NF- $\kappa B$ kinase (IKK), a key regulator of NF- $\kappa B$ activation, by oxidizing cysteine residues Cys114 and Cys115. In NF- $\kappa B$ reporter mice, topical $\mathrm{HOCl}$ reduced LPS-induced NF- $\kappa B$ signaling in skin. We further evaluated topical $\mathrm{HOCl}$ use in two mouse models of NF- $\kappa B$-driven epidermal disease. For mice with acute radiation dermatitis, topical $\mathrm{HOCl}$ inhibited the expression of $\mathrm{NF}-\kappa \mathrm{B}-$ dependent genes, decreased disease severity, and prevented skin ulceration. In aged mice, topical $\mathrm{HOCl}$ attenuated age-dependent production of $\mathrm{p}^{16^{\mathrm{INK}} 4 \mathrm{a}}$ and expression of the DNA repair gene Rad50. Additionally, skin of aged HOCl-treated mice acquired enhanced epidermal thickness and proliferation, comparable to skin in juvenile animals. These data suggest that topical $\mathrm{HOCl}$ reduces $\mathrm{NF}-\kappa \mathrm{B}$-mediated epidermal pathology in radiation dermatitis and skin aging through IKK modulation and motivate the exploration of $\mathrm{HOCl}$ use for clinical aims.
\end{abstract}

\section{Introduction}

Hypochlorite $(\mathrm{HOCl})$ is used worldwide in homes, health care offices, and swimming pools in concentrations ranging between $0.005 \%$ and $6 \%$. Dilute HOCl baths $(0.005 \% \mathrm{v} / \mathrm{v})$ are used for treating human atopic dermatitis (1), but it remains controversial whether disease improvement reflects antiinflammatory or antimicrobial effects (2). HOCl functions as an oxidant and may interfere with cellular signaling processes by oxidizing key mediator(s). We and others have previously shown that nuclear factor- $\kappa \mathrm{B}$ $(\mathrm{NF}-\mathrm{\kappa B})$ activates proinflammatory gene programs $(3,4)$ and that $\mathrm{NF}-\kappa \mathrm{B}$ transcriptional activity is sensitive to intracellular reduction-oxidation (redox) conditions (5). Thus, $\mathrm{HOCl}$ may modulate NF- $\mathrm{KB}$ signaling and inflammatory responses in the skin.

NF- $\kappa \mathrm{B}$ is activated by a wide variety of stimuli including TNF, LPS, and ionizing irradiation (6). NF- $\mathrm{KB}$ plays an integral role in important and diverse processes, including human inflammatory responses, immune system development, apoptosis, and aging. In resting cells, NF- $\mathrm{KB}$ is a dimeric protein sequestered in the cytoplasm via its association with inhibitory proteins called

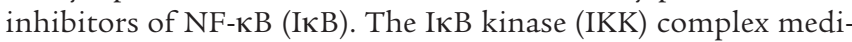
ates IKB protein phosphorylation and is composed of two catalytic subunits, IKK $\alpha$ and IKK $\beta$. Upon cell stimulation, IKB proteins are phosphorylated, ubiquitinated, and degraded. NF- $\kappa B$ then enters the nucleus and activates appropriate target genes.

Previous work has revealed a role for NF- $\mathrm{KB}$ in skin development, aging, and radiation response. Mice with a skin-restricted genetic NF-кB deletion (7) or with overexpression of an inhibitor of NF-кB exhibited epidermal hyperplasia, increased cell proliferation, and normal keratinocyte maturation $(8,9)$. Moreover, mice with a skin-restricted genetic deletion of IKK $\alpha$ or IKK $\beta$ also demonstrated epidermal hyperplasia and disrupted skin homeostasis (10). With

Conflict of interest: The authors have declared that no conflict of interest exists. Citation for this article: J Clin Invest. 2013;123(12):5361-5370. doi:10.1172/JCI70895. age, NF- $\kappa \mathrm{B}$ activity increases in many tissues. Conditional genetic inhibition of NF-KB in aged mice restored molecular and cellular features of juvenile skin, and in two different mouse models of accelerated aging, the inhibition of NF- $\kappa \mathrm{B}$ delayed age-related phenotypes (11-13). Finally, ionizing irradiation initiates cellular responses driven by classical activation of NF- $\mathrm{KB}$ and can induce radiation dermatitis, a common adverse side effect in patients undergoing radiation therapy that has no standardized clinical treatment $(10,14,15)$. Therefore, direct inhibitors of the NF-אB pathway should be useful in clinical medicine.

Here, we demonstrate that dilute $\mathrm{HOCl}$ oxidizes and inhibits IKK function in vitro and in vivo. This inhibitory effect was lost in cells where endogenous IKK $\beta$ was replaced with a Cys ${ }^{114-115}$ to Ala ${ }^{114-115}$ mutant. Strikingly, dilute HOCl baths helped treat or ameliorate two NF- $\kappa \mathrm{B}$-driven conditions in mice: acute radiation dermatitis and aging. Our findings provide a mechanistic basis for understanding the efficacy of $\mathrm{HOCl}$ in human diseases like atopic dermatitis and show that $\mathrm{HOCl}$ could be used in other NF- $\mathrm{KB}-$ driven disease processes.

\section{Results}

$H O C l$ reversibly inbibits $T N F-\alpha-$ stimulated $N F-\kappa B$-dependent gene expression in buman keratinocytes. To test whether HOCl modulates NF-кB signaling, we measured the induction of established NF-кB-dependent inflammatory genes CCL2 (chemokine ligand-2 or MCP-1) and SOD2 (superoxide dismutase 2) in primary human keratinocytes stimulated with TNF- $\alpha$. Exposure of human keratinocytes to $0.005 \% \mathrm{HOCl}$ for 1 hour prior to TNF- $\alpha$ stimulation eliminated the induction of both genes (Figure 1A). Cell death was not increased in $\mathrm{HOCl}$-treated cells, and $\mathrm{HOCl}$ did not alter the media $\mathrm{pH}$, which can affect TNF- $\alpha$ responsiveness (Figure 1B). By contrast, CCL2 and SOD2 mRNA induction were unaffected in keratinocytes exposed to $\mathrm{HOCl}$ for 1 hour and then treated with TNF- $\alpha 24$ hours later, suggesting that $\mathrm{HOCl}$ effects are reversible (Figure 1C). Thus, 
A

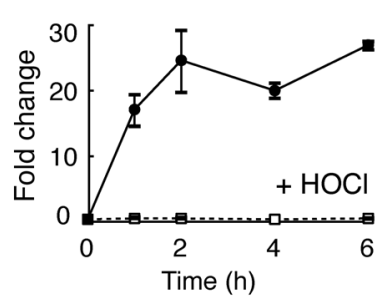

C

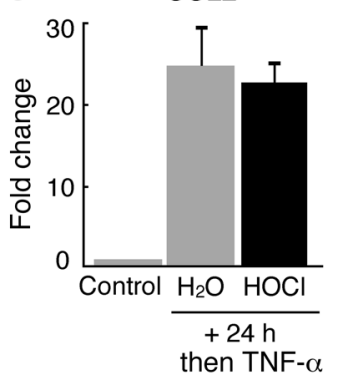

SOD2

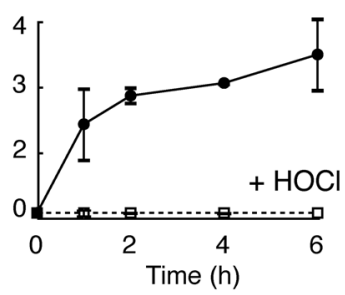

SOD2

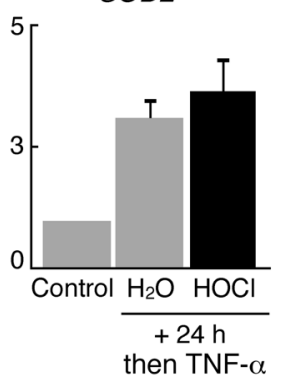

$\mathrm{HOCl}$ reversibly inhibited TNF- $\alpha$-stimulated NF-кB-dependent gene induction in primary human keratinocytes.

$H O C l$ inbibits $N F-\kappa B$ signaling independently of $I \kappa B$. We extended these results using cultured mouse fibroblasts. HOCl blocked NF-KB-dependent gene expression induced either by TNF- $\alpha$ or LPS stimulation (Figure 2, A and B, and Supplemental Figure 1A; supplemental material available online with this article; doi:10.1172/JCI70895DS1), ligands that activate the NF-кB pathway through independent receptors, suggesting that $\mathrm{HOCl}$ inhibits intracellular NF- $\mathrm{KB}$ signaling. Using mouse genetics and a cell line that permits in vivo monitoring of NF- $\kappa \mathrm{B}$ cellular location, we showed that $\mathrm{HOCl}$ blocks nuclear translocation of all NF-KB dimers, suggesting that $\mathrm{HOCl}$ inhibits cytoplasmic functions that regulate NF- $\kappa \mathrm{B}$ activation (ref. 3 and Figure 2, C-E). $\mathrm{HOCl}$ blocked NF- $\kappa \mathrm{B}$-dependent gene expression in a dose-dependent manner (Supplemental Figure 1B). By contrast, $\mathrm{HOCl}$ induced the expression of Hmox1 (heme oxygenase 1 or HO-1), a known oxidation-sensitive enzyme, and increased p38 MAPK phosphorylation (Figure 2, F and G). Thus, while $\mathrm{HOCl}$ inhibited intracellular NF-кB signaling, it did not impair gene transcription and protein signaling in all pathways.

Previous work demonstrated that chloramines like $\mathrm{HOCl}$ can

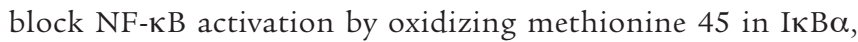
generating I $\mathrm{B} \boldsymbol{\alpha} \alpha$ forms resistant to TNF- $\alpha$-induced degradation (16-18). We tested whether $\mathrm{HOCl}$ inhibited NF-кB signaling in I $\mathrm{B} \alpha$-deficient cells, which maintain NF- $\kappa \mathrm{B}$ signaling through

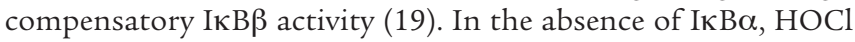
pretreatment still blocked TNF- $\alpha$-stimulated Cxcl10 mRNA induction (Figure $2 \mathrm{H}$ ). Western blot analysis showed that $\mathrm{HOCl}$ exposure inhibited TNF- $\alpha$-induced degradation of both IкB $\alpha$ and

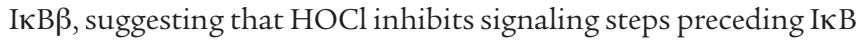
protein degradation (Figure 2I). Consistent with this view, $\mathrm{HOCl}$ pretreatment in wild-type cells prevented TNF- $\alpha$-stimulated IкB $\alpha$ Ser32 phosphorylation, a modification mediated by the IKK complex that precedes IKB $\alpha$ degradation (Supplemental Figure 1C). Thus, HOCl impeded TNF- $\alpha$-stimulated phosphorylation and degradation of IкB proteins.

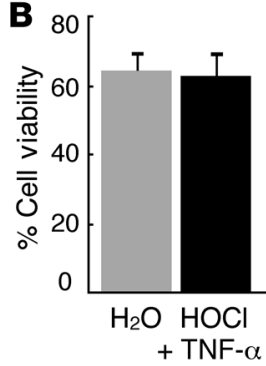

\section{Figure 1}

$\mathrm{HOCl}$ reversibly inhibits TNF- $\alpha-$ stimulated NF-кB-dependent gene expression in primary human keratinocytes. (A) Relative mRNA levels of CCL2 and SOD2 in TNF- $\alpha-$ stimulated human keratinocytes with (dotted line) and without (solid line) $\mathrm{HOCl}$ pretreatment. (B) Cell viability assessed by trypan blue after $\mathrm{HOCl}$ treatment. (C) Relative mRNA levels of CCL2 and SOD2 in human keratinocytes pretreated with $\mathrm{H}_{2} \mathrm{O}$ or $\mathrm{HOCl} ; 24$ hours later, cells were stimulated with TNF- $\alpha$ for 2 hours. Control represents untreated keratinocytes. Data are presented as the average \pm SEM. Conditions with and without $\mathrm{HOCl}$ treatment are denoted by black and gray bars, respectively.
To test whether other oxidants also block NF-кB activation, we pretreated cultured mouse fibroblasts with hydrogen peroxide $\left(\mathrm{H}_{2} \mathrm{O}_{2} ; 90 \mu \mathrm{M}\right)$ and measured TNF- $\alpha$-stimulated induction of $\mathrm{Ccl} 2$ and $\mathrm{Hmox} 1 \mathrm{mRNAs} . \mathrm{H}_{2} \mathrm{O}_{2}$ exposure induced Hmox 1 transcript levels, indicating an appropriate cellular oxidative stress response. However, $\mathrm{H}_{2} \mathrm{O}_{2}$ pretreatment did not block TNF- $\alpha$-stimulated $\mathrm{Ccl} 2$ expression (Figure 2J). Thus, $\mathrm{HOCl}$, but not $\mathrm{H}_{2} \mathrm{O}_{2}$, can inhibit NF- $\mathrm{BB}$ activation.

HOCloxidizes and inactivates IKK. Since IKK proteins phosphorylate and target IКB proteins for degradation, we assessed the effects of $\mathrm{HOCl}$ on IKK function. IKK is composed of the catalytic subunits IKK $\alpha$ and IKK $\beta$. IKK $\alpha$ regulates noncanonical NF- $\mathrm{B}$ signaling by a group of TNF-like receptors, including lymphotoxin $\beta$ receptor (LT $\beta R$ ) (19). LT $\beta$ R activates NF- $\kappa B$ by proteasomal processing of the NF- $\mathrm{KB}$ precursor protein $\mathrm{p} 100$ into the mature $\mathrm{p} 52$ subunit, thereby stimulating expression of target genes including $\mathrm{Ccl} 2$ (20). As expected, in LT $\beta$ R-exposed wild-type cells, we observed an accumulation of $\mathrm{p} 52$ protein and induced Ccl2 expression. Both responses were eliminated by $\mathrm{HOCl}$ pretreatment (Figure 3, A and B). TNF- $\alpha$-stimulated IKK $\beta$ activation requires phosphorylation at Ser177/Ser181. HOCl pretreatment blocked this phosphorylation, suggesting that $\mathrm{HOCl}$ inhibits IKK $\beta$ function (Figure 3C). Collectively, $\mathrm{HOCl}$ inhibits both IKK $\alpha$ and IKK $\beta$.

Previous studies suggest that IKK is oxidation sensitive, but the underlying mechanism remains unexplored $(21,22)$. Moreover, depending on the context, oxidants can activate or inhibit NF-кB (14). Thus we performed a kinase assay using activated recombinant human IKK $\beta$ and showed that $\mathrm{HOCl}$ inhibited IKK $\beta$ kinase activity (ref. 23 and Figure 3D, left panel). Concomitant addition of dithiothreitol (DTT), a strong reducing agent, blocked $\mathrm{HOCl}$ inhibition of IKK $\beta$ kinase activity (Figure 3D, middle panel), consistent with the hypothesis that $\mathrm{HOCl}$ inhibits IKK by oxidation. In contrast, sequential exposure of recombinant IKK $\beta$ protein to $\mathrm{HOCl}$ followed by DTT resulted in reduced IKK $\beta$ kinase activity (Figure 3D, right panel), suggesting that $\mathrm{HOCl}$ irreversibly oxidizes IKK $\beta$. We observed earlier that HOCl-mediated inhibition of NF- $\kappa \mathrm{B}$ signaling is reversible (Figure 1C), and 

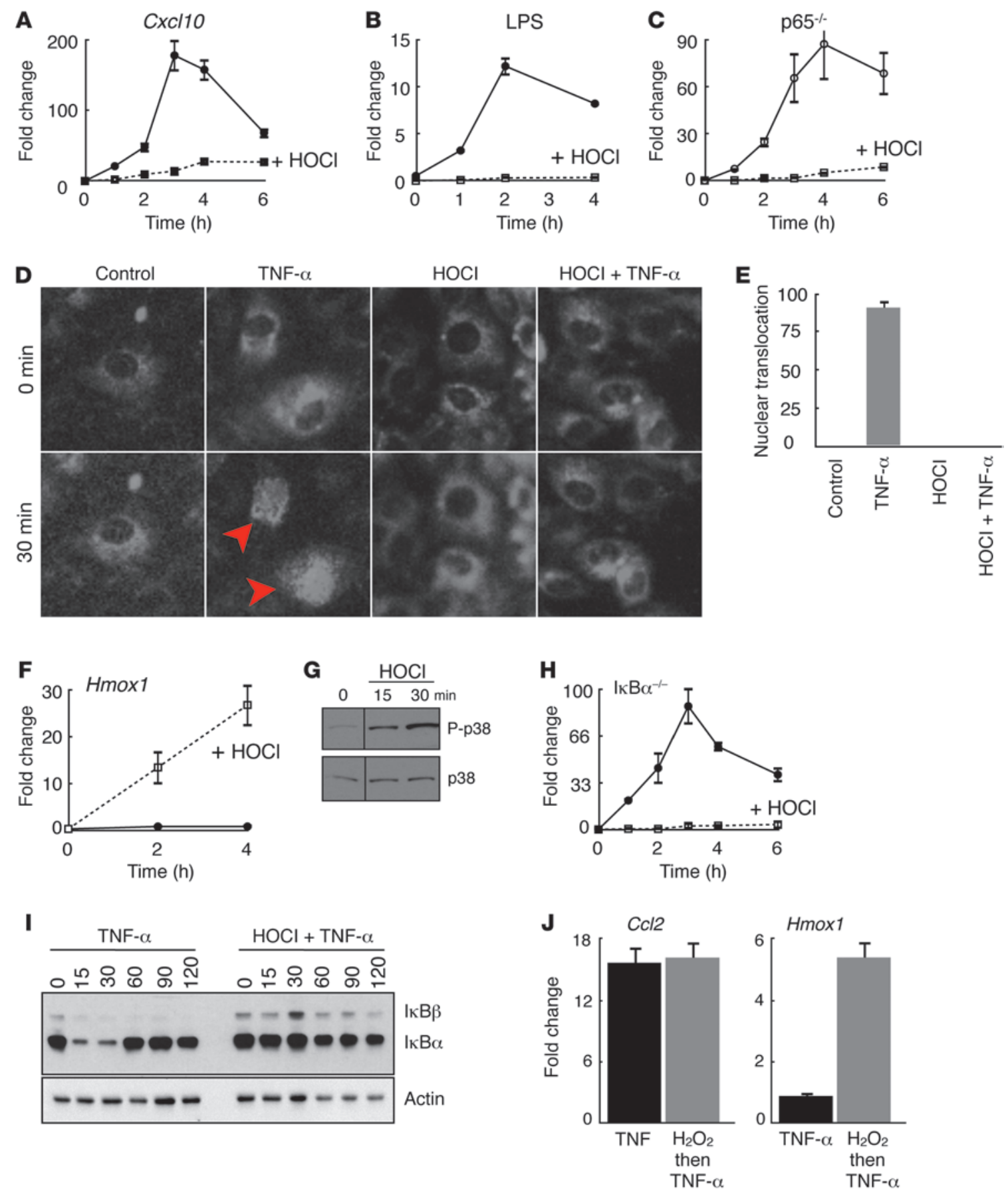

\section{Figure 2}

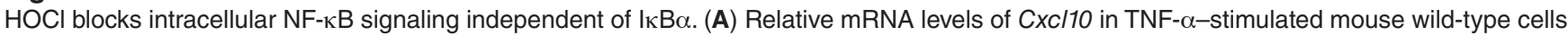
with (dotted line) and without (solid line) $\mathrm{HOCl}$ pretreatment. (B) Relative fold changes of luciferase activity in LPS-stimulated transgenic wildtype cells carrying an integrated NF-KB reporter gene driving luciferase with (dotted line) and without (solid line) $\mathrm{HOCl}$ pretreatment. (C) Relative mRNA transcript levels of Cc/2 mRNA in TNF- $\alpha$-stimulated p65-deficient cells with (dotted line) and without (solid line) HOCl pretreatment. (D) Visualization of TNF- $\alpha-$ stimulated p65-dsRed nuclear translocation (TNF- $\alpha$ panels; red arrows). HOCl pretreatment blocks TNF- $\alpha-$ stimulated p65-dsRed fusion protein nuclear translocation ( $\mathrm{HOCl}$ and $\mathrm{HOCl}+\mathrm{TNF}-\alpha$ panels). (E) Quantification of p65-dsRed nuclear translocation per 100 cells. (F) Relative mRNA transcript levels of Hmox1 in TNF- $\alpha$-stimulated mouse wild-type cells with (dotted line) and without (solid line) HOCl pretreatment. (G) Western blot analysis of phospho-p38 (P-p38) and total p38 protein in HOCl-treated cells. Black lines indicate a grouping of images from different parts of the same gel. (H) Relative mRNA levels of $C x c / 10$ in TNF- $\alpha$-stimulated IкB $\alpha$-deficient cells with (dotted line) and without (solid line) $\mathrm{HOCl}$ pretreatment. (I) Western blot analysis of $I_{\kappa} \mathrm{B} \alpha$ and $\mathrm{I}_{\kappa} \mathrm{B} \beta$ protein levels in TNF- $\alpha-$ stimulated wild-type cells with and without $\mathrm{HOCl}$ pretreatment. (J) Relative $\mathrm{Ccl} 2$ and $\mathrm{Hmox} 1 \mathrm{mRNA}$ transcript levels in TNF- $\alpha$-stimulated wild-type cells with (gray bars) and without (black bars) $\mathrm{H}_{2} \mathrm{O}_{2}$ pretreatment. Data are presented as the average \pm SEM. 

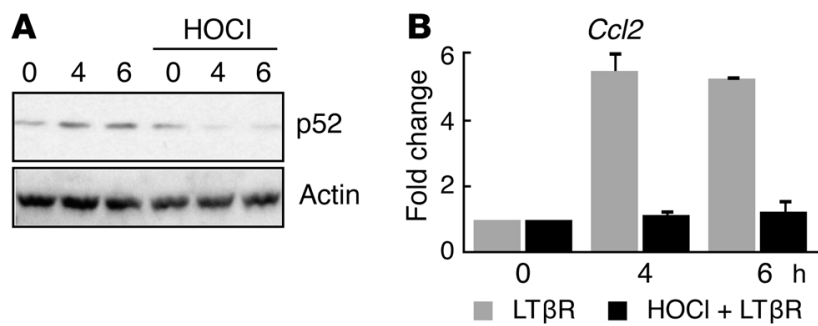

D
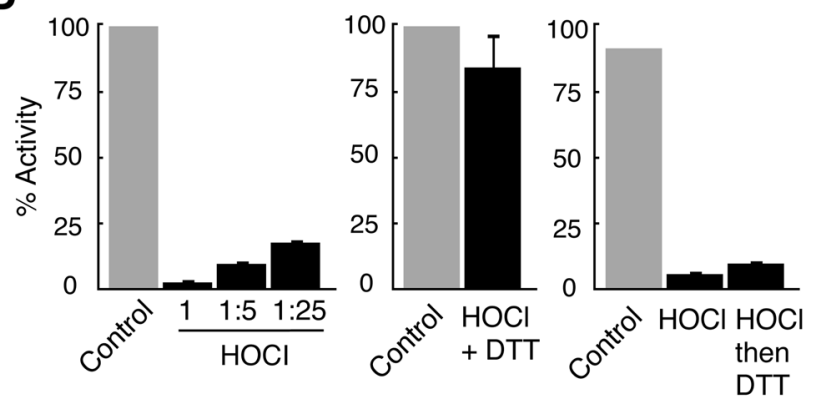

C

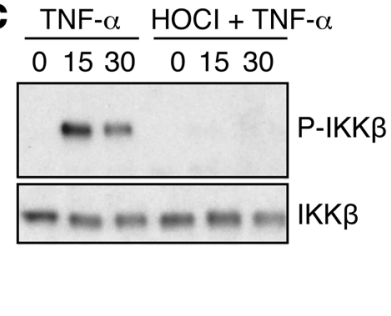

\section{Figure 3}

$\mathrm{HOCl}$ inhibits IKK function by oxidizing cysteines 114-115. (A) Western blot analysis of 552 protein levels and (B) relative Cc/2 mRNA transcript levels in LT $\beta$ R-stimulated mouse wild-type cells with (black bars) and without (gray bars) $\mathrm{HOCl}$ pretreatment. (C) Western blot analysis of phospho-IKK $\beta$-Ser176/180 in TNF- $\alpha$-stimulated wild-type cells with and without $\mathrm{HOCl}$ pretreatment. (D) Relative kinase activity of recombinant IKK $\beta$ protein with decreasing amounts of $\mathrm{HOCl}$ (left panel), simultaneous addition of DTT and $\mathrm{HOCl}$ (middle panel), and sequential addition of $\mathrm{HOCl}$ then DTT (right panel). (E) Percentage of induction of $\mathrm{Cc} / 2$ transcript in $\mathrm{HOCl}$-pretreated TNF- $\alpha$-stimulated wild-type cells with (gray bars) and without (black bars) cycloheximide treatment. ${ }^{\star} P=0.004$. (F) Percentage inhibition of $\mathrm{Cc} / 2$ transcript levels in TNF- $\alpha-$ stimulated IKK $\beta$-deficient cells reconstituted with the $l k k b$ transgene; wild-type and four mutant transgenes of IKK $\beta$ are shown. Alleles encoding indicated cysteine-to-alanine missense mutations are denoted as C99A, C114A/C115A, C412A, and C525A. C114A/C115A is a double mutant. (G) Relative Cc/2 mRNA transcript levels in TNF- $\alpha$-stimulated wild-type cells with (gray bar) or without (black bar) $\mathrm{HOCl}$ pretreatment in the presence of SnPP. ${ }^{*} P<0.001$. Data are presented as the average \pm SEM.
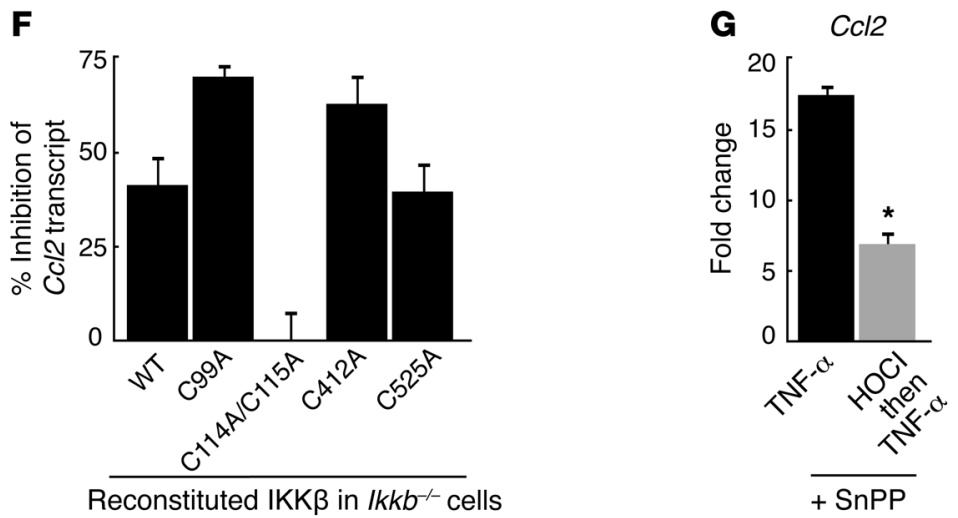

now we have identified an irreversible modification by HOCl. This difference is likely reconciled by ongoing IKK $\beta$ protein turnover. Consistent with this possibility, cycloheximide treatment, which inhibits protein synthesis, significantly prolonged the duration of HOCl-mediated NF- $\mathrm{BB}$ inhibition (Figure 3E).

HOCl inhibits IKK $\beta$ by oxidizing cysteines 114-115. Methionine and cysteine residues are amino acids commonly modified by oxidation (24). While methionine oxidation is reversible, oxidation of cysteine to cysteic acid is irreversible. Mass spectrometry (MS) of untreated and $\mathrm{HOCl}$-treated IKK $\beta$ protein identified five cysteines that were oxidized to cysteic acid at residues 99, 114, 115, 412, and 525 . Cysteines 99, 114, and 115 were conserved between IKK $\alpha$ and IKK $\beta$ as well as between orthologs of IKK (Table 1). To assess whether the substitution of cysteine with an oxidation-resistant amino acid produces an $\mathrm{HOCl}$-resistant variant of IKK $\beta$, we mutated individual cysteines with alanine (designated C99A, C114A/C115A, C412A, or C525A; Cys114 and Cys115 were simultaneously altered in one construct) and expressed mutated IKK $\beta$ in IKK $\beta$-deficient cells (25). Each mutant cell line had similar TNF- $\alpha$-stimulated $\mathrm{Ccl} 2$ induction compared with wild-type cells, indicating reconstituted, intact IKK $\beta$ function (Supplemental Figure 2, A and B). When these cells were pretreated with $\mathrm{HOCl}$ followed by TNF- $\alpha$ stimulation, the $\mathrm{HOCl}$ effect was lost only in cells expressing the
IKK $\beta^{\mathrm{C} 114 \mathrm{~A}-\mathrm{C} 115 \mathrm{~A}}$ variant (Figure 3F). Expression levels of IKK $\beta^{\mathrm{WT}}$

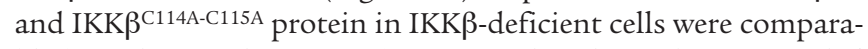
ble (Supplemental Figure 2C). Structural analysis of IKK $\beta$ revealed that Cys114 and Cys115 mediate critical interactions between the kinase and dimerization domains $(26,27)$. Although not identified in our analysis, Cys179 of IKK $\beta$ has been shown to be oxidation sensitive (28), and replacement of Cys179 with alanine did not alter its sensitivity to $\mathrm{HOCl}$ (Supplemental Figure 2D). Taken together, our findings indicate that oxidation of Cys ${ }^{114-115}$ to cysteic acid is responsible for $\mathrm{HOCl}$-mediated IKK $\beta$ inactivation.

NRF2 (nuclear factor [erythroid-derived 2]-like 2 or NFE2L2) regulates cellular responses to oxidative stress and induces HMOX1, a major effector protein (29). Thus, it is possible that $\mathrm{HOCl}$ pretreatment induced a strong antioxidant response driven by the NRF2 pathway to inhibit TNF- $\alpha$-induced NF- $\kappa$ B activation. To test whether the Nrf2 pathway is needed for HOCl-mediated NF- $\mathrm{KB}$ inhibition, we treated cells with an established pharmacologic inhibitor of HMOX1 protein, tin protoporphyrin (SnPP) (30). In HOCl-pretreated WT cells exposed to TNF- $\alpha$ and SnPP, Hmox 1 and Nrf2 transcript levels were significantly induced, consistent with increased oxidative cellular stress (ref. 31 and Supplemental Figure 3). In these SnPP-treated cells, $\mathrm{HOCl}$ still inhibited TNF- $\alpha$-stimulated Ccl2 


\section{Table 1}

IKK $\beta$ cysteines irreversibly oxidized to cysteic acid as assessed by MS

$\begin{array}{lc}\text { Cysteine } & \text { Location } \\ 99 & \text { Kinase domain } \\ 114 & \text { Critical for kinase domain and dimerization domain interaction } \\ 115 & \text { Critical for kinase domain and dimerization domain interaction } \\ 412 & \text { Dimerization domain } \\ 525 & \text { Dimerization domain }\end{array}$

$\begin{array}{cc}\text { Conserved in orthologs } & \text { Conserved in IKK } \alpha \\ \text { Y } & \text { Y } \\ \text { Y } & \text { Y } \\ \text { Y } & \text { Y } \\ \text { N } & \text { N } \\ \text { N } & \text { N }\end{array}$

induction (Figure 3G). Thus, inhibition of NF-אB signaling by $\mathrm{HOCl}$ likely does not require NRF2-dependent responses.

$\mathrm{HOCl}$ blocks in vivo NF-KB activation. To assess whether $\mathrm{HOCl}$ could inhibit NF- $\kappa \mathrm{B}$ signaling in vivo, we used an established $\mathrm{NF}-\kappa \mathrm{B}$ reporter mouse line that expresses a luciferase transgene from NF-KB-responsive cis-regulatory elements (26). Reporter mouse abdominal skin was exposed to $\mathrm{HOCl}$ or water (control) for 30 minutes, followed by LPS injection to activate NF-кB systemically. Two hours after LPS injection, the isolated epidermis of water-treated control mice had a 6-fold induction of reporter activity, an effect that was reduced by $50 \%$ in HOCl-treated animals (Figure 4A). Thus, a single, brief exposure to topical $\mathrm{HOCl}$ markedly blocked in vivo NF-КB signaling in skin epidermis. Next,

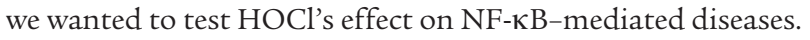

$\mathrm{HOCl}$ ameliorates acute radiation dermatitis. We used an established model of radiation dermatitis to test whether $\mathrm{HOCl}$ affects the development of acute radiation dermatitis in vivo (32). Radiation dermatitis was reproducibly induced on the backs of 4-week-old C57BL/ 6 female mice with 6 Gy irradiation for 10 days. Skin was examined daily and assessed using Radiation Therapy Oncology Group (RTOG) criteria, which grades skin ulceration as the highest score (grade 4). Skin ulceration is defined as round excavations that result in the complete loss of epidermis and some portion of the dermis. To test the effect of $\mathrm{HOCl}$, before each dose of ionizing irradiation, we immersed the back skin of C57BL/6 mice in $\mathrm{HOCl}$ (or water for control mice) for 30 minutes. Irradiated skin in control mice initially developed erythema (days 10-12) followed by patchy moist desquamation (days 13-15) (Figure 4B, top panels, and Supplemental Figure 4). On day 20, irradiated skin began to develop skin ulcerations that continued to worsen through day 30 (Figure 4B, top panels, red arrowheads). HOCl-treated irradiated skin demonstrated mild-to-moderate erythema with intact epidermis. While the irradiated skin of all control animals eventually developed ulcerations, none of the HOCl-treated irradiated skin ulcerated, even by day 30 (Figure 4B, bottom panels). While a small area of HOCl-treated irradiated skin developed an intact scar, most of the HOCl-treated irradiated skin showed hair regrowth, indicating that intact hair follicles were maintained in the irradiated skin area (Supplemental Figure 4). This is consistent with the phenomenon of anagen effluvium, which is described in patients following radiation or chemotherapy treatment $(33,34)$. Overall, HOCl-treated animals had significantly reduced RTOG scores across the time course, with scores of $1.8 \pm 0.24$ and $4.0 \pm 0$ with and without $\mathrm{HOCl}$ treatment, respectively, by day 30 (Figure 4C).

Histological analysis of skin biopsies taken on day 14 revealed that the skin of irradiated control animals exhibited classical signs of radiation dermatitis, including a lichenoid infiltrate, loss of skin appendages, and epidermal/dermal swelling (Figure 4D, top panel). In contrast, the skin of HOCl-treated animals was largely normal, with retention of skin appendages and a mild increase in dermal cellularity (Figure 4D, lower panel; skin appendages are denoted by red arrowheads). Finally, irradiation of mouse skin induced the expression of five well-established NF-кB-dependent genes, and $\mathrm{HOCl}$ exposure significantly diminished this response (Figure 4E). Taken together, $\mathrm{HOCl}$ treatment markedly attenuated radiation-induced expression of NF-KB-dependent genes, ameliorated the severity of acute radiation-induced dermatitis and prevented skin ulceration.

$H O C l$ reverses the hallmark features of epidermal aging. Aged skin is characterized by epidermal thinning and decreased proliferative capacity. In newborn mice, the epidermis comprises 3-4 cell layers and thins to 1 to 2 cell layers with age (Figure 5A, top and middle panels). To test whether $\mathrm{HOCl}$ inhibition of NF-кB might rejuvenate skin in vivo, we immersed the abdominal skin of 18-monthold C57BL/ 6 female mice in $\mathrm{HOCl}$ (or water for control mice) for 30 minutes daily for 2 weeks. After each treatment, both $\mathrm{HOCl}$ treated and control animals were rinsed in water. $\mathrm{HOCl}$ exposure induced epidermal hyperplasia (Figure 5A, bottom panel). The average epidermal thickness increased more than 2-fold compared with water-treated control mice and approached the same thickness found in young mice (Figure 5B). Histology did not reveal any evidence of inflammation in the epidermis or dermis of mice exposed to HOCl. After treatment cessation, HOCl-induced epidermal thickening rapidly diminished within 1 week and was largely lost by 2 to 3 weeks (Figure 5B), suggesting that the beneficial effect is reversible and requires sustained $\mathrm{HOCl}$ exposure.

During normal skin development, keratinocytes in the basal layer adjacent to the basement membrane proliferate, then undergo cell-cycle arrest and migrate to outward layers, where they terminally differentiate. Consistent with the increase in epidermal thickness, $\mathrm{HOCl}$ treatment increased the expression of Ki-67, a cell proliferation marker, from $8 \%$ to $28 \%$ (Figure 5, C and D). Cell proliferation in $\mathrm{HOCl}$-exposed animals only occurred in the basal layer of keratinocytes, the normal proliferative compartment. Similar to a study of primary fibroblasts, primary human keratinocytes treated with $\mathrm{HOCl}$ had significantly increased rates of cell proliferation (ref. 35 and Supplemental Figure 5). Rejuvenated skin also exhibited proper spatial organization of mature stratified epidermis, including expression of keratin 14 in the basal layer, keratin 10 in the suprabasal layer, and loricrin in the granular layer (Figure 5E). Keratin 17 is a marker of hyperproliferation and truncated epidermal differentiation (36); in HOCl-rejuvenated skin, we did not detect inappropriate keratin 17 expression in the epidermis. Rather, we found appropriate expression of keratin 17 in hair follicles and infundibulum (the opening of the hair follicle into the epidermis) (Figure 5F, white arrowheads). In skin diseases 
A

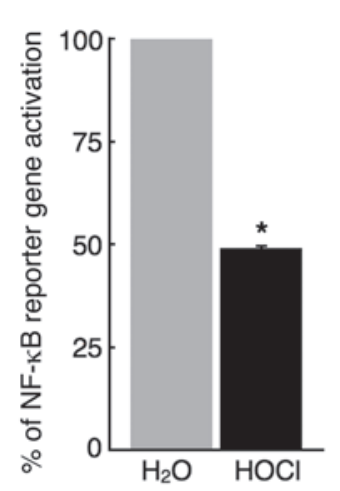

C

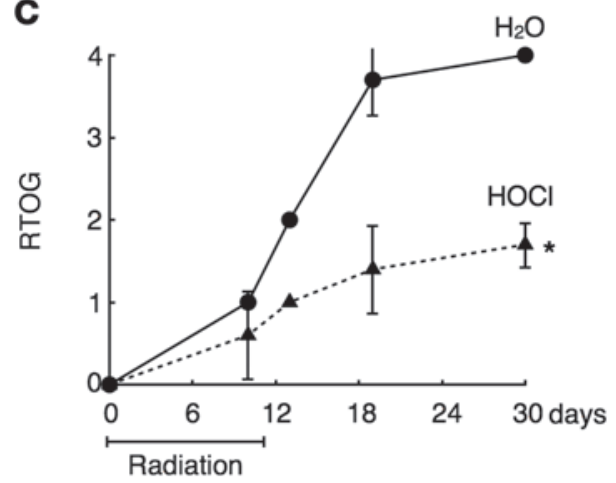

B

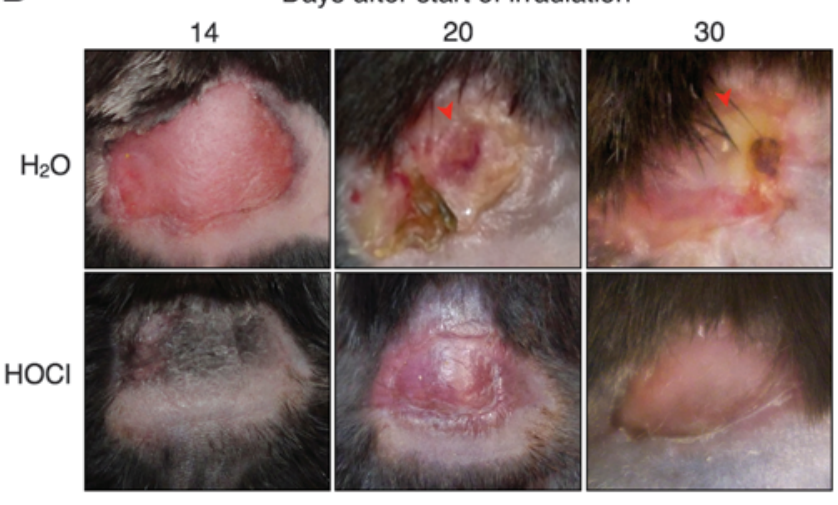

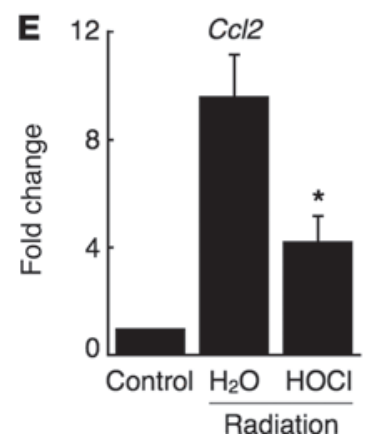
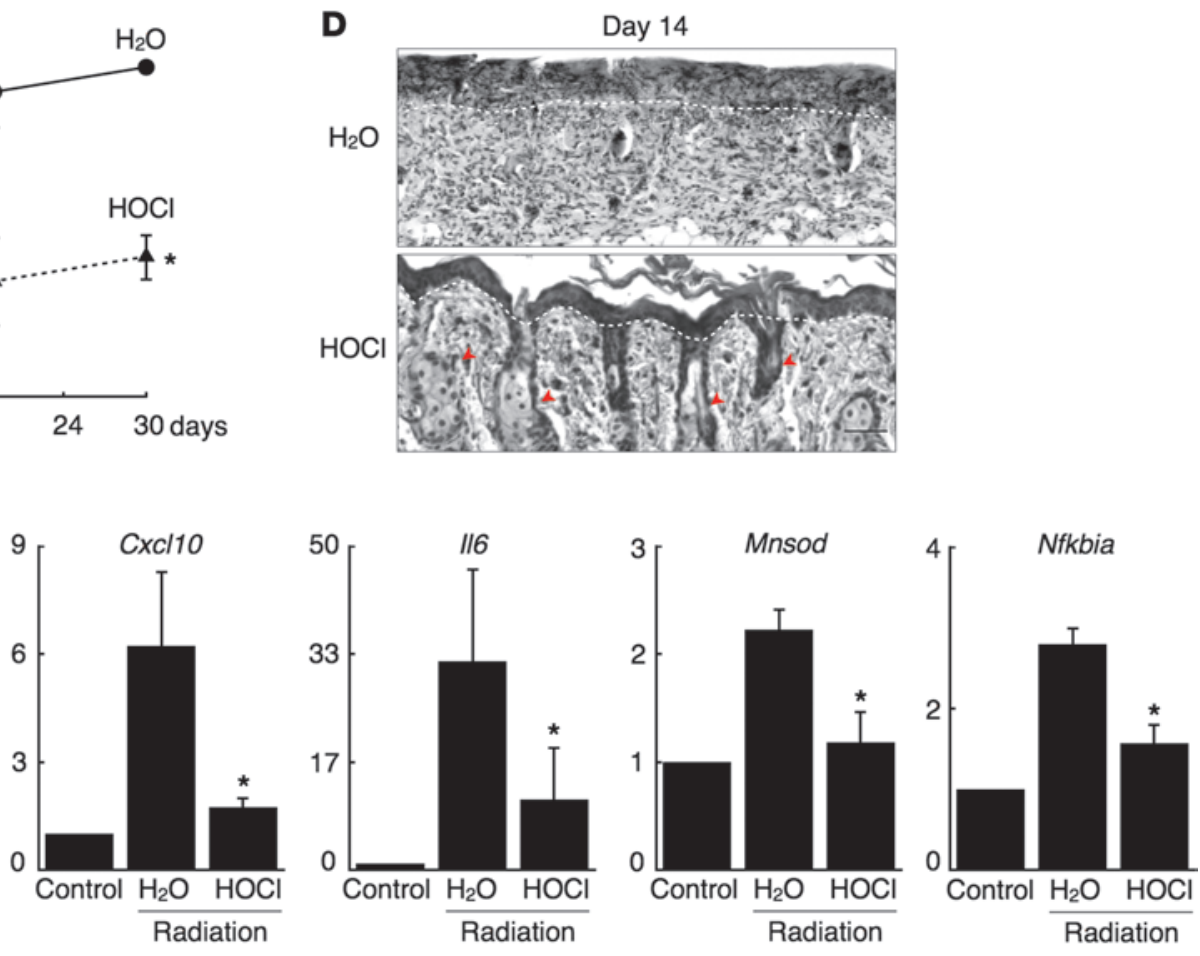

\section{Figure 4}

$\mathrm{HOCl}$ attenuates acute radiation dermatitis. (A) Relative percentage of NF- $\mathrm{KB}$ reporter gene activation in the skin of LPS-stimulated NF- $\mathrm{kB}$ reporter mice treated topically with and without $\mathrm{HOCl}\left(n=3\right.$ in each group). ${ }^{*} P<0.01$. Four-week-old mice received 6 Gy irradiation daily for 10 days on their back skin. Prior to each dose of radiation, mice were treated with $\mathrm{H}_{2} \mathrm{O}$ or $\mathrm{HOCl}(n=5-7$ for each treatment group). (B) Images taken of the back skin on days 14, 20, and 30 after the start of irradiation. Representative images are selected from each group. (C) Score based on RTOG criteria for radiation-induced dermatitis in mice treated with $\mathrm{H}_{2} \mathrm{O}$ or $\mathrm{HOCl}$. ${ }^{*} P<0.001$ comparing treatment groups across $14-, 20,-$ and 30 -day time points. $P<0.01$ for individual 14-, 20-, and 30-day time points. (D) H\&E staining of epidermis from indicated mice on day 14 . White dashed line indicates basement membrane; red arrows indicate skin appendages. Scale bar: $20 \mu \mathrm{m}$. Representative images selected from each group. (E) Relative mRNA levels of Cc/2, Cxcl10, II6, Mnsod, and Nfkbia in back skin isolated from irradiated mice treated with $\mathrm{H}_{2} \mathrm{O}$ or $\mathrm{HOCl}$ on day 14 ( $n=4-6$ for each treatment group). Control obtained from untreated mouse back skin. ${ }^{*} P<0.05$ for all genes. Data are presented as the average \pm SEM.

of hyperproliferation, keratin 10 expression was reduced or eliminated, but in HOCl-rejuvenated skin, keratin 10 expression was maintained (Figure 5E and ref. 37).

Skin aging induces the expression of RAD50, a DNA repair protein, and $\mathrm{p} 16^{\mathrm{INK} 4 \mathrm{~A}}$, a cell-cycle regulator $(11,12,38)$. The expression of these two markers was significantly reduced in the epidermis of aged mice exposed to $\mathrm{HOCl}$ treatment to a level comparable to that found in 2-day-old mice (Figure 6,
A-C). Taken together, $\mathrm{HOCl}$ induced epidermal hyperplasia, with increased cell proliferation and reversal of two agingassociated genes, while maintaining normal tissue homeostasis and differentiation, effects that require sustained exposure to $\mathrm{HOCl}$ (Figure 5B). These results are consistent with the previous findings that mice lacking NF- $\mathrm{KB}$ activity in the epidermis exhibit epidermal hyperplasia and increased cell proliferation, while maintaining normal keratinocyte maturation $(7,9)$. 
A

$2 d$

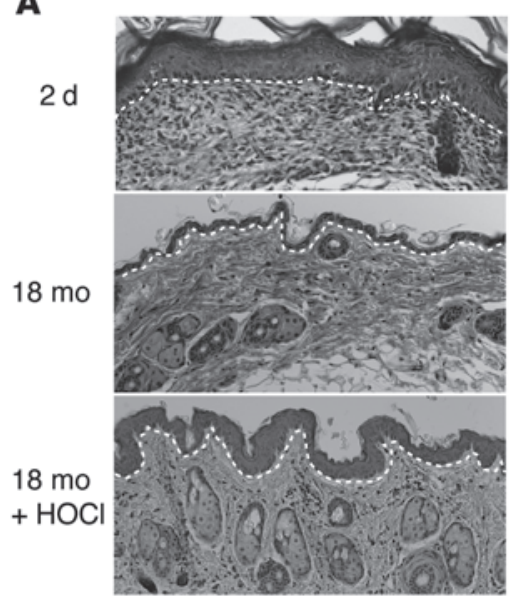

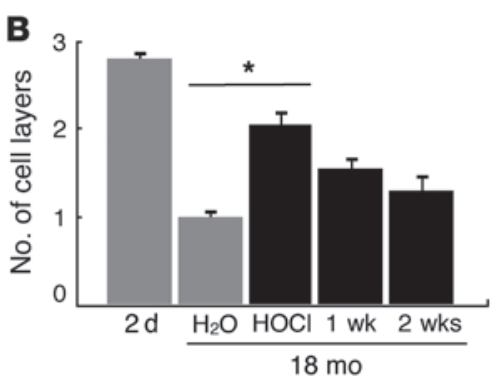

D

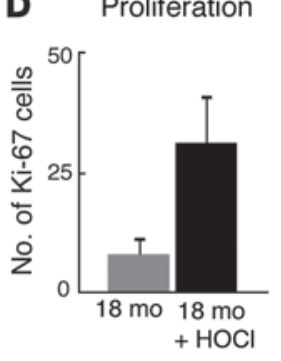

C

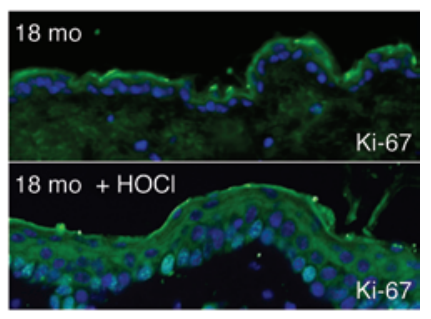

F

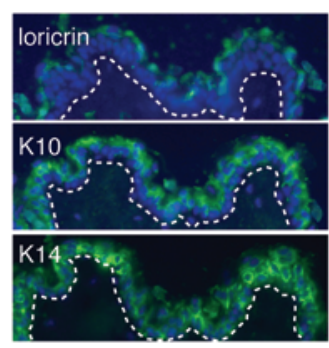

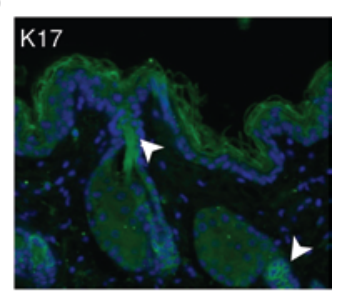

\section{Figure 5}

$\mathrm{HOCl}$ treatment induces epidermal hyperplasia and cell proliferation while maintaining normal skin architecture. Data from 2-day-old mice (2 d) and 18-month-old mice treated topically with $\mathrm{H}_{2} \mathrm{O}(18 \mathrm{mo})$ or $\mathrm{HOCl}(18 \mathrm{mo}+\mathrm{HOCl})$ for 14 days $(n=11$ for each 18 -month-old treatment group; $n=3$ for 2-day-old mice). (A) H\&E staining of epidermis from indicated mice. (B) Average epidermal thickness (number of cell layers) for each treatment group. Skin thickness from the 18-month-old plus $\mathrm{HOCl}$ group was determined 1 week and 2 weeks after cessation of $\mathrm{HOCl}(n=3$ for the $\mathrm{HOCl}$ treatment groups 1 week and 2 weeks after cessation of treatment). ${ }^{*} P=0.001$. (C) Ki-67 immunostaining (green) on paraffin-embedded sections of 18-month-old mouse skin with and without $\mathrm{HOCl}$ treatment. (D) Percentage of basal keratinocytes expressing Ki-67. (E) Keratin 14 (K14), keratin 10 (K10), and loricrin immunostaining (green), and (F) keratin 17 (K17) immunostaining (green) on paraffin-embedded sections of skin from the 18-month-old plus $\mathrm{HOCl}$ treatment group. Expected staining in the lower portion of the hair follicle and hair infundibulum is denoted with white arrowheads. White dashed line in $\mathbf{E}$ indicates basement membrane. Nuclei in panels $\mathbf{C}$, $\mathbf{E}$, and $\mathbf{F}$ were counterstained with DAPI (blue). Original magnification, $\times 20(\mathbf{A}, \mathbf{C}, \mathbf{E}$ and $\mathbf{F})$. Representative images were selected from each group. (B and $\mathbf{D})$ Conditions with and without $\mathrm{HOCl}$ are denoted by black and gray bars, respectively. Data are presented as the average \pm SEM.

\section{Discussion}

Previous studies have shown that oxidants can either induce or repress NF- $\mathrm{KB}$ signaling in a context- and cell type-specific manner, but little is known about the involved mechanism(s) or their potential effect in vivo (5). Our studies reveal that $\mathrm{HOCl}$ oxidizes IKK irreversibly at Cys114 and Cys115 to cysteic acid in order to inhibit NF-KB signaling in human keratinocytes; Cys114 and Cys 115 are conserved between IKK $\alpha$ and IKK $\beta$, and HOCl likely inhibits both subunits. This inhibitory effect is likely mediated by steric hindrance due to cysteic acid, and not by the disruption of disulfide bonds, since the IKK $\beta$ Cys114-115 to Ala mutants retain their inducible function. The possible effects of $\mathrm{HOCl}$ on targets other than IKK are not ruled out by our work; HOCl may oxidize regulatory cysteines in other proteins to affect their function. After $\mathrm{HOCl}$ removal, NF- $\mathrm{\kappa B}$ signaling is likely restored by new synthesis of IKK protein.

Our data also suggest that oxidants can affect signaling pathways in a relatively specific manner. Although $\mathrm{HOCl}$ and $\mathrm{H}_{2} \mathrm{O}_{2}$ are in the same oxidant class and induced cellular antioxidant responses to a similar degree, only $\mathrm{HOCl}$ blocked NF- $\mathrm{KB}$ signaling. These distinct responses likely reflect intrinsic chemical differences between $\mathrm{H}_{2} \mathrm{O}_{2}$ and $\mathrm{HOCl} . \mathrm{H}_{2} \mathrm{O}_{2}$ biological effects are mainly due to secondary products, and $\mathrm{H}_{2} \mathrm{O}_{2}$ is thought to covalently modify biological macromolecules only rarely. Compared with $\mathrm{H}_{2} \mathrm{O}_{2}, \mathrm{HOCl}$ has a relative reaction rate with glutathione that is $10^{7}$-fold greater (39), indicating that $\mathrm{HOCl}$ is a more potent oxi- dant. $\mathrm{HOCl}$ also preferentially reacts with thiol residues, including cysteines (35). HOCl is naturally produced by neutrophils in the phagosome, and similar oxidative modifications can be found under biologically relevant conditions (40). Taken together, the ability of $\mathrm{HOCl}$ to modify IKK directly may explain why only some oxidants can block NF-кB signaling.

We also show that $\mathrm{HOCl}$ functions in vivo to attenuate two distinct and different NF- $\kappa \mathrm{B}-$ driven disease processes: acute radiation dermatitis and aging. In our in vivo mouse models, we infer that $\mathrm{HOCl}$ is predominantly inhibiting NF- $\mathrm{KB}$ signaling in keratinocytes. In our radiation dermatitis experiments, many of the assessed NF-KB-dependent genes are cytokines produced in epithelial cells and known to recruit inflammatory cells; by inhibiting cytokine production, fewer immune cells can be recruited to the skin, thereby decreasing inflammation and subsequent tissue damage. In our aging model, our observations are consistent with prior studies that used conditional genetics to reduce NF-KB signaling specifically in keratinocytes for the alteration of skin homeostasis (10). Moreover, histologic analysis of rejuvenated skin did not reveal any gross changes in dermal cell populations. Thus, our data support the hypothesis that the primary effect of $\mathrm{HOCl}$ is on keratinocytes, but other studies are needed to assess the possibility that dermal cells are affected.

NF-кB signaling increases with age in diverse tissues, likely through a combination of genetic and epigenetic mechanisms. Heterochronic parabiosis experiments have demonstrated that 
A
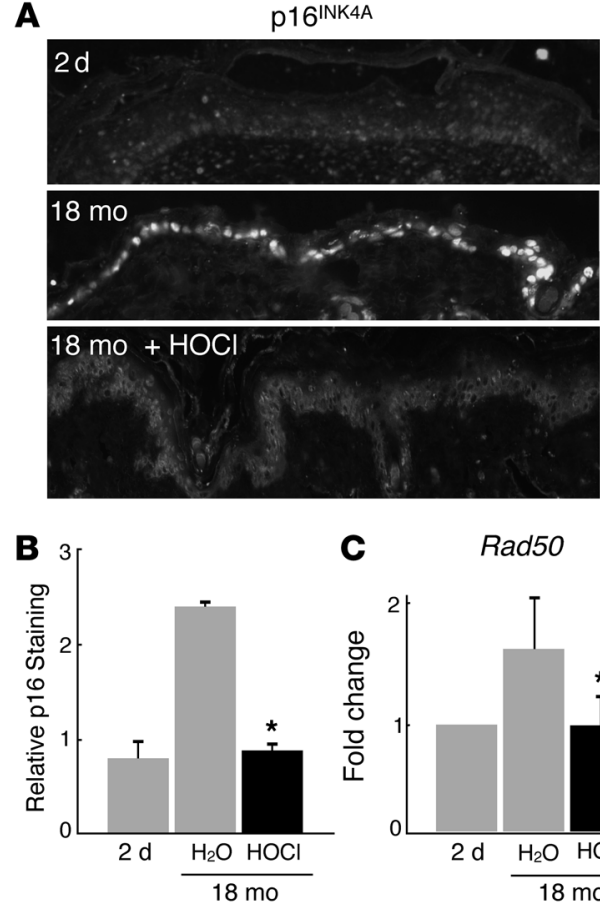

C

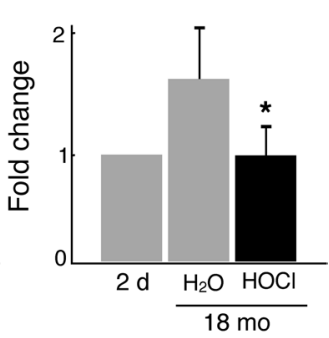

youthful features can be restored in aged tissues, which suggests that some features of aging are reversible $(41,42)$. We speculate that NF-KB blockade may reverse the epigenetic programs underlying skin aging. By rejuvenating aged skin to a more youthful state, $\mathrm{HOCl}$ may promote the treatment of skin pathologies exacerbated by aging. It is known that cutaneous wounds in the elderly heal much slower than in the young (43). HOCl may help treat chronic nonhealing wounds, including sacral decubitus pressure ulcers, trauma-induced wounds, and diabetic foot ulcers. These are common clinical problems that lack effective treatments and represent an important unmet clinical need (44). Radiation dermatitis is a common side effect in cancer patients undergoing radiation therapy that also lacks effective treatments or prevention regimens.

Bortezomib is the sole compound in clinical formularies used to target NF- $\mathrm{KB}$ signaling in human cancers, albeit in an indirect manner. Bortezomib inhibits proteasome function, thereby blocking IКB degradation, and treatment is associated with significant systemic toxicities. By contrast, $\mathrm{HOCl}$ is a safe, well-characterized, inexpensive, and widely available topical agent. Dilute concentrations of $\mathrm{HOCl}$ are used in swimming pools and medical clinics with minimal toxicities in humans. For example, $\mathrm{HOCl}$ has proven clinical efficacy in human atopic dermatitis. To our knowledge, there have been no reports of $\mathrm{HOCl}$-induced premalignant skin changes. Thus, although our current study is limited to in vivo findings in mouse models, our observations should motivate clinical testing of $\mathrm{HOCl}$ in radiation dermatitis and aging skin. Future clinical trials will be required to assess the responses of aged skin to $\mathrm{HOCl}$ and to define optimal treatment strategies. Finally, our studies suggest that topical $\mathrm{HOCl}$ treatment may be readily extended to other NF-KB-driven inflammatory disease processes.

\section{Methods}

Materials. $\mathrm{HOCl}$ (Clorox) was diluted in $\mathrm{H}_{2} \mathrm{O}$ or DMEM media for a final concentration of $0.005 \%$. We use "HOCl" to describe this mixture.

\section{Figure 6}

$\mathrm{HOCl}$ reverses markers of epidermal aging. Data from control 2-dayold mice and 18-month-old mice treated topically with $\mathrm{H}_{2} \mathrm{O}$ or $\mathrm{HOCl}$ for 14 days ( $n=7-11$ for each 18-month-old treatment group; $n=3$ for 2-day-old mice). (A) p16 INK4A immunostaining. (B) Quantification of $\mathrm{p} 16^{\text {INK4A }}$ immunostaining. ${ }^{*} P=0.03$. (C) Relative mRNA levels of Rad50. ${ }^{*} P=0.001$. Black bars represent $\mathrm{HOCl}$ treatment. Original magnification, $\times 20$. Representative immunohistochemistry images for each group are shown. Data are presented as the average \pm SEM.

Cell culture. Primary human keratinocytes were a gift from Paul Khavari (Stanford University). They were grown and passaged as previously described (45). IKK $\alpha$, IKK $\beta$, and IKK $\alpha / \operatorname{IKK} \beta$ doubly deficient MEFs were provided by Inder Verma (Salk Institute, San Diego, California, USA). Transgenic mouse fibroblasts harboring an NF- $\mathrm{B}$ reporter gene driving luciferase have been previously described (4). Cells were maintained as previously described (46). Cells at $100 \%$ confluence were treated for 48 hours with medium containing $0.5 \%$ serum and then stimulated with the appropriate concentration of TNF- $\alpha(10 \mathrm{ng} / \mathrm{ml}$; Roche), LPS $(0.5 \mu \mathrm{g} / \mathrm{ml}$; Sigma-Aldrich), or LT $\beta R$ ( $2 \mu \mathrm{g} / \mathrm{ml}$; Enzo Life Sciences) over a period of 0 to 6 hours. Cycloheximide $(25 \mu \mathrm{g} / \mathrm{ml}$; Sigma-Aldrich) or tin protoporphyrin $(10 \mu \mathrm{M}$, Santa Cruz Biotechnology Inc.) was added to the media as indicated in Figure 2J and Figure 3E. The luciferase assay was performed according to the manufacturer's instructions (Promega). Cell proliferation quantification was performed using CellTiter-Blue per the manufacturer's instructions (Promega).

Animals. Transgenic NF- $\kappa \mathrm{B}$ reporter mice harboring a luciferase reporter gene driven by NF- $\kappa \mathrm{B}-$ binding sites were purchased from Taconic. C57BL/6 female mice (18-20 months of age) were purchased from the National Institute on Aging. C57BL/6 mating pairs were purchased from The Jackson Laboratory. All mice were housed in the animal facility of Stanford University on a 12-hour light/12-hour dark cycle with ad libitum access to water and normal chow.

Dilute HOCl baths. Prior to the experiment, the hair of the lower abdomen or the back of each mouse was shaved closely with an electric razor. Fiveliter buckets containing $500 \mathrm{ml}$ of $\mathrm{H}_{2} \mathrm{O}$ or dilute $\mathrm{HOCl}(0.005 \%)$ at $37^{\circ} \mathrm{C}$ were prepared. One mouse was placed into each bucket; the water level allowed each mouse to stand comfortably on four feet. After 30 minutes, each mouse was removed and placed for 5 minutes into a second 5-liter bucket containing $\mathrm{H}_{2} \mathrm{O}$ at $37^{\circ} \mathrm{C}$. Afterward, each mouse was dried and returned to its cage.

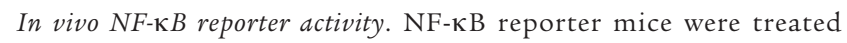
with a control or dilute $\mathrm{HOCl}$ bath as described above. LPS $(2 \mathrm{mg} / \mathrm{kg}$; Sigma-Aldrich) was injected via the tail vein. After 2 to 3 hours, the mice were injected with d-luciferin ( 130 mg/kg; Sigma-Aldrich). The mice were euthanized 5 minutes later, and the abdominal skin was isolated. Bioluminescence imaging of the abdominal skin was performed using a Xenogene IVIS 200 system (PerkinElmer). Luminescence was measured regularly for 20 minutes, and multiple readings were collected and averaged for each sample.

IKK kinase assay and MS. The IKK assay was performed according to the manufacturer's instructions (Cell Signaling Technology). MS was performed at the Stanford University Mass Spectrometry Core Facility. Protein solution samples were prepared by performing $-80^{\circ} \mathrm{C}$ acetone precipitation, followed by reconstitution in $8 \mathrm{M}$ urea, $50 \mathrm{mM}$ ammonium bicarbonate, and $0.2 \%$ ProteaseMAX solution (Promega). DTT reduction and propionamide alkylation were performed, followed by trypsin (Promega) digestion overnight at $37^{\circ} \mathrm{C}$. Liquid chromatographric-mass spectrometric (LC-MS) analysis was performed, using an LTQ Orbitrap Velos mas spectrometer (Thermo Scientific) set in high-low data-depen- 
dent fashion to perform tandem MS (MS/MS) on the top twelve most intense precursor ions. A Proxeon EASY-nLC (Thermo Scientific) was set at a flow rate of $300 \mathrm{nl} /$ minute using a self-packed nano C18 LC column. Data were searched against the International Protein Index (IPI) Human v. 3.66 Fasta database (Matrix Science) using SEQUEST with $20 \mathrm{ppm}$ precursor mass tolerance on a SORCERER platform, where data visualization and analysis were performed with Scaffold proteome software (Proteome Software).

Real-time RT-PCR. Cells for RT-PCR analysis were collected in TRIzol (Invitrogen). Total RNA was isolated using Direct-zol RNA MiniPrep (Zymo Research). The RNA concentration was measured by Nanodrop 1000 (Thermo Scientific). cDNA synthesis was performed with Maxima Reverse Transcriptase (Thermo Scientific) per the manufacturer's instructions. One-step quantitative RT-PCR was performed and analyzed using an ABI Prism 7300 detection system (Applied Biosystems) with TaqMan one-step RT-PCR Master Mix Reagents or SYBR Green one-step RT-PCR Master Mix Reagents (Applied Biosystems). TaqMan probes were purchased for mouse (RAD50, CCL2, CXCL10, I16, MNSOD, NFKBIA, HMOX1, and NRF2) and human (SOD2, CCL2) genes (Life Technologies). Primer sequences for mouse genes assessed by SYBR Green chemistry are described in the Supplemental Methods.

Western blot analysis. Total protein was prepared from cultured cells by direct application of SDS sample buffer. Equal amounts of protein were resolved on SDS-PAGE and transferred to polyvinylidine fluoride membranes (Amersham Pharmacia) for immunoblotting with specific antibodies, including rabbit polyclonal anti-IкB $\alpha(1: 1,000)$; rabbit monoclonal anti-phospho-IкB $\alpha(1: 1,000)$; rabbit polyclonal anti-IKK $\beta(1: 1,000)$; rabbit polyclonal anti-IKK $\alpha$ (1:1,000); rabbit monoclonal phospho-IKK $\alpha$ (Ser176)/IKK $\beta$ (Ser177) (1:1,000); rabbit polyclonal anti-p100/p52; rabbit monoclonal phospho-p38 MAPK (1:1,000); rabbit monoclonal p38 MAPK (1:1000) (all from Cell Signaling Technology); and rabbit polyclonal anti$\beta$-actin-HRP (1:5,000; Santa Cruz Biotechnology Inc.). Signal was visualized using ECL detection (Amersham Pharmacia) on Kodak film after further incubation with HRP-conjugated secondary antibodies.

Mutant plasmids. To generate mutant plasmids, a human IKK $\beta$ cDNA expression vector (gift from D. Goeddel, Column Group, San Francisco, California, USA) was cloned into a lentiviral vector with puromycin selection (System Biosciences). Missense mutations were created by PCR mutagenesis. Plasmid constructions were verified by DNA sequencing and restriction enzyme analysis.

Histology, immunofluorescence, and immunohistochemistry. Standard histological PFA fixation, paraffin embedding, and immunostaining protocols were performed. Briefly, immunohistochemical analysis was performed on 5 - $\mu \mathrm{m}$-thick sections of mouse skin after antigen retrieval (Vector Laboratories) using the following primary antibodies: mouse monoclonal anti-Ki67 (1:100; Novocastra); rabbit polyclonal anti-keratin 14 (1:100; Covance); rabbit polyclonal anti-keratin 10 (1:100; Covance); rabbit polyclonal anti-loricrin (1:100; Covance); mouse monoclonal anti-p16 (1:100; Santa Cruz Biotechnology Inc.); and rabbit monoclonal keratin 17/19 (1:100; Cell Signaling Technology). Immune complexes were detected with secondary antibodies conjugated with either CY3, fluorescein isothiocyanate (Jackson ImmunoResearch), or HRP (Vector Laboratories). After staining, the images were directly analyzed on an AxioM1 microscope equipped with a CCD digital camera (Carl Zeiss).

Relative protein expression was quantified on a 0 to 3 scale: 0 indicates no staining; 1 signifies weak staining; 2 indicates intermediate staining; and 3 signifies strong staining. A score was obtained every $250 \mu \mathrm{m}$ (p16INK4A) of epidermis (minimum of $5 \mathrm{~mm}$ ) for each sample and then averaged. The number of Ki- $67^{+}$cells was counted every $250 \mu \mathrm{m}$ of epidermis (minimum of $5 \mathrm{~mm}$ ) for each sample and then averaged.
NF-אB cellular localization. p65-deficient cells harboring a $\mathrm{p} 65$ promoter driving p65-dsRed fusion protein were provided by Markus Covert (Stanford University). An assay was performed as previously described (47).

Radiation dermatitis. Radiation dermatitis was induced as previously described (32). Briefly, a 2- $\mathrm{cm}^{2}$ area of skin on the back was irradiated locally at $6 \mathrm{~Gy}$ daily for 10 consecutive days. Ionizing irradiation was adminstered using a Philips RT-250 200kVp x-ray machine $(12.5 \mathrm{~mA}$, half value layer, $1.0 \mathrm{~mm} \mathrm{Cu}$ ). To induce dermatitis, unanesthetized mice were placed in individual lead boxes with skin protruding through a cut-out window at the rear of each box. Skin reaction to radiation was assessed according to the RTOG score system (48). Grade 0: no change over baseline. Grade 1: follicular, faint, or dull erythema/epilation/dry; desquamation/decreased sweating. Grade 2: tender or bright erythema, patchy moist desquamation/ moderate edema. Grade 3: confluent, moist desquamation other than skin folds, pitting edema. Grade 4: ulceration, hemorrhage, necrosis.

Hydrogen peroxide experiments. Cells at $100 \%$ confluence were treated for 48 hours with medium containing $0.5 \%$ serum. On the day of the experiment, DMEM (Hyclone) containing no serum was used to treat the cells with $90 \mu \mathrm{M}$ hydrogen peroxide (CVS) and then stimulated with the appropriate concentration of TNF- $\alpha$ ( $10 \mathrm{ng} / \mathrm{ml}$; Roche).

Statistics. A 2-tailed Student's $t$ test was used to determine significance, with $P$ values of less than 0.05 considered significant. Higher levels of significance $(P<0.01 ; P<0.001)$ are indicated in the text. For Figure $4 \mathrm{C}$, we followed the nonparametric analysis of ordinal data method $(49,50)$. The method used was a repeated-measures ANOVA for ordinal data. We considered two factors: treatment (control vs. HOCI) and time (14, 20, and 30 days) and an interaction term (treatment $\times$ time). The treatment factor allowed us to study differences between the control and HOCI groups, the time factor allowed us to study differences among the three time points, and the interaction term allowed us to determine whether differences between the control and HOCI groups were consistent over time. The analysis was implemented using SAS Macro (SAS Institute Inc.) (50).

Study approval. Experiments involving mice were reviewed and approved by the IACUC of Stanford University. Mice were treated in accordance with NIH guidelines for the humane care of animals.

\section{Acknowledgments}

We thank B. Zarnegar, G. McLean, R. Mann, the Stanford Imaging Core, and the Stanford Mass Spectrometry Core for technical assistance; M. Covert (Stanford University), D. Goeddel (Column Group), P. Khavari (Stanford University), J. Pomerantz (Johns Hopkins University), and I. Verma (Salk Institute for Biological Studies) for reagents; D. Leung (Singapore Management University) for statistical analysis support; A. Lane (Stanford University) for helpful discussions; and D. Baltimore (Caltech), S. Smale (UCLA), and members of the Kim laboratory for critical readings of this manuscript. T.H. Leung received funding from an NIH T32 Training Grant (DK007217-38) and the Dermatology Foundation. This work was supported by the Howard Hughes Medical Institute (HHMI). S.K. Kim is an HHMI Investigator.

Received for publication May 6, 2013, and accepted in revised form September 12, 2013.

Address correspondence to: Seung Kim, Department of Developmental Biology, Howard Hughes Medical Institute, Beckman Center B300, Stanford University School of Medicine, 279 Campus Drive, Stanford, California 94305-5329, USA. Phone: 650.723.6230; Fax: 650.725.7739; E-mail: seungkim@stanford.edu. 
1. Huang JT, Abrams M, Tlougan B, Rademaker A, Paller AS. Treatment of Staphylococcus aureus colonization in atopic dermatitis decreases disease severity. Pediatrics. 2009;123(5):e808-e814.

2. Rutala WA, Cole EC, Thomann CA, Weber DJ. Stability and bactericidal activity of chlorine solutions. Infect Control Hosp Epidemiol. 1998;19(5):323-327.

3. Covert MW, Leung TH, Gaston JE, Baltimore D. Achieving stability of lipopolysaccharide-induced NF-KB activation. Science. 2005;309(5742):1854-1857.

4. Leung TH, Hoffmann A, Baltimore D. One nucleotide in a $\mathrm{\kappa B}$ site can determine cofactor specificity for NF-КB dimers. Cell. 2004;118(4):453-464.

5. Gloire G, Legrand-Poels S, Piette J. NF-кB activation by reactive oxygen species: fifteen years later. Biochem Pharmacol. 2006;72(11):1493-1505.

6. Hayden MS, Ghosh S. NF- $\mathrm{KB}$, the first quarter-century: remarkable progress and outstanding questions. Genes Dev. 2012;26(3):203-234.

7. Gugasyan R, et al. The transcription factors c-rel and RelA control epidermal development and homeostasis in embryonic and adult skin via distinct mechanisms. Mol Cell Biol. 2004;24(13):5733-5745.

8. Seitz CS, Lin Q, Deng H, Khavari PA. Alterations in NF- $\mathrm{KB}$ function in transgenic epithelial tissue demonstrate a growth inhibitory role for NF-кB. Proc Natl Acad Sci U S A. 1998;95(5):2307-2312.

9. Zhang JY, Green CL, Tao S, Khavari PA. NF-кB RelA opposes epidermal proliferation driven by TNFR1 and JNK. Genes Dev. 2004;18(1):17-22.

10. Pasparakis M. Role of NF- $\kappa B$ in epithelial biology. Immunol Rev. 2012;246(1):346-358.

11. Adler AS, Sinha S, Kawahara TL, Zhang JY, Segal E, Chang HY. Motif module map reveals enforcement of aging by continual NF-кB activity. Genes Dev. 2007;21(24):3244-3257.

12. Tilstra JS, et al. NF- $\mathrm{B}$ inhibition delays DNA damage-induced senescence and aging in mice. J Clin Invest. 2012;122(7):2601-2612.

13. Osorio FG, et al. Nuclear lamina defects cause ATM-dependent NF- $\mathrm{B}$ activation and link accelerated aging to a systemic inflammatory response. Genes Dev. 2012;26(20):2311-2324.

14. Brach MA, Hass R, Sherman ML, Gunji H, Weichselbaum R, Kufe D. Ionizing radiation induces expression and binding activity of the nuclear factor $\kappa$ B. J Clin Invest. 1991;88(2):691-695.

15. Chan RJ, Larsen E, Chan P. Re-examining the evidence in radiation dermatitis management literature: an overview and a critical appraisal of systematic reviews. Int J Radiat Oncol Biol Phys. 2012;84(3):e357-e362.

16. Kanayama A, Inoue J, Sugita-Konishi Y, Shimizu

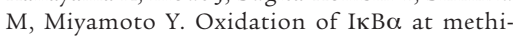
onine 45 is one cause of taurine chloramine-induced inhibition of NF-кB activation. J Biol Chem. 2002;277(27):24049-24056

17. Midwinter RG, Cheah FC, Moskovitz J, Vissers MC, Winterbourn CC. IkappaB is a sensitive target for oxidation by cell-permeable chloramines: inhibition of NF- $\mathrm{KB}$ activity by glycine chloramine through methionine oxidation. Biochem J. 2006;396(1):71-78.

18. Ogino T, Hosako M, Hiramatsu K, Omori M, Ozaki M, Okada S. Oxidative modification of IкB by monochloramine inhibits tumor necrosis factor

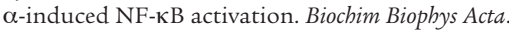
2005; 1746(2):135-142.

19. Sun SC. Non-canonical NF-кB signaling pathway. Cell Res. 2011;21(1):71-85.

20. Lovas A, et al. Differential RelA- and RelB-dependent gene transcription in LT $\beta R$-stimulated mouse embryonic fibroblasts. BMC Genomics. 2008;9:606.

21. Korn SH, Wouters EF, Vos N, Janssen-Heininger YM. Cytokine-induced activation of nuclear factor- $\mathrm{K} \mathrm{B}$ is inhibited by hydrogen peroxide through oxidative inactivation of IКB kinase. J Biol Chem. 2001;276(38):35693-35700.

22. Loukili $\mathrm{N}$, et al. Oxidants positively or negatively regulate nuclear factor $\mathrm{\kappa B}$ in a context-dependent manner. J Biol Chem. 2010;285(21):15746-15752.

23. Miller BS, Zandi E. Complete reconstitution of human IKB kinase (IKK) complex in yeast. Assessment of its stoichiometry and the role of IKK $\gamma$ on the complex activity in the absence of stimulation. J Biol Chem. 2001;276(39):36320-36326.

24. Miki H, Funato Y. Regulation of intracellular signalling through cysteine oxidation by reactive oxygen species. J Biochem. 2012;151(3):255-261.

25. Li Q, Estepa G, Memet S, Israel A, Verma IM. Complete lack of NF- $\kappa$ B activity in IKK1 and IKK2 double-deficient mice: additional defect in neurulation. Genes Dev. 2000;14(14):1729-1733.

26. Carlsen H, Alexander G, Austenaa LM, Ebihara K, Blomhoff R. Molecular imaging of the transcription factor NF- $\kappa B$, a primary regulator of stress response. Mutat Res. 2004;551(1-2):199-211.

27. Xu G, et al. Crystal structure of inhibitor of $\kappa \mathrm{B}$ kinase $\beta$. Nature. 2011;472(7343):325-330.

28. Pandey MK, Sandur SK, Sung B, Sethi G, Kunnumakkara AB, Aggarwal BB. Butein, a tetrahydroxychalcone, inhibits nuclear factor (NF)- $\mathrm{B}$ and NF- $\kappa \mathrm{B}$-regulated gene expression through direct inhibition of I $\mathrm{B} \alpha$ kinase $\beta$ on cysteine 179 residue. J Biol Chem. 2007;282(24):17340-17350.

29. Wei Y, et al. Hypochlorous acid-induced heme oxygenase-1 gene expression promotes human endothelial cell survival. Am J Physiol Cell Physiol. 2009;297(4):C907-C915.

30. Kappas A, Drummond GS. Control of heme metabolism with synthetic metalloporphyrins. J Clin Invest. 1986;77(2):335-339.

31. La P, et al. Zinc protoporphyrin regulates cyclin D1 expression independent of heme oxygenase inhibition. J Biol Chem. 2009;284(52):36302-36311.

32. Ning S, Budas GR, Churchill EN, Chen CH, Knox SJ, Mochly-Rosen D. Mitigation of radiation-induced dermatitis by activation of aldehyde dehydrogenase 2 using topical alda- 1 in mice. Radiat Res.
2012;178(1):69-74.

33. Ali SY, Singh G. Radiation-induced alopecia. Int J Trichology. 2010;2(2):118-119.

34. Chon SY, Champion RW, Geddes ER, Rashid RM. Chemotherapy-induced alopecia. J Am Acad Dermatol. 2012;67(1):e37-e47.

35. Hidalgo E, Dominguez C. Growth-altering effects of sodium hypochlorite in cultured human dermal fibroblasts. Life Sci. 2000;67(11):1331-1344.

36. Kurokawa I, Takahashi K, Moll I, Moll R. Expression of keratins in cutaneous epithelial tumors and related disorders - distribution and clinical significance. Exp Dermatol. 2011;20(3):217-228.

37. Stoler A, Kopan R, Duvic M, Fuchs E. Use of monospecific antisera and cRNA probes to localize the major changes in keratin expression during normal and abnormal epidermal differentiation. J Cell Biol. 1988;107(2):427-446.

38. Krishnamurthy J, et al. Ink4a/Arf expression is a biomarker of aging. J Clin Invest. 2004; 114(9):1299-1307.

39. Winterbourn CC. Reconciling the chemistry and biology of reactive oxygen species. Nat Chem Biol. 2008;4(5):278-286.

40. Winterbourn CC, Kettle AJ. Redox reactions and microbial killing in the neutrophil phagosome. Antioxid Redox Signal. 2013;18(6):642-660.

41. Conboy IM, Rando TA. Heterochronic parabiosis for the study of the effects of aging on stem cells and their niches. Cell Cycle. 2012;11(12):2260-2267.

42. Rando TA, Chang HY. Aging, rejuvenation, and epigenetic reprogramming: resetting the aging clock. Cell. 2012;148(1-2):46-57.

43. Danon D, Kowatch MA, Roth GS. Promotion of wound repair in old mice by local injection of macrophages. Proc Natl Acad Sci US A. 1989;86(6):2018-2020.

44. Moore Z, Cowman S. A systematic review of wound cleansing for pressure ulcers. J Clin Nurs. 2008;17(15):1963-1972.

45. Deng H, Choate KA, Lin Q, Khavari PA. High-efficiency gene transfer and pharmacologic selection of genetically engineered human keratinocytes. BioTechniques. 1998;25(2):274-280.

46. Hoffmann A, Leung TH, Baltimore D. Genetic analysis of NF- $\kappa \mathrm{B} /$ Rel transcription factors defines functional specificities. EMBO J. 2003; 22(20):5530-5539.

47. Tay S, Hughey JJ, Lee TK, Lipniacki T, Quake SR, Covert MW. Single-cell NF-KB dynamics reveal digital activation and analogue information processing. Nature. 2010;466(7303):267-271.

48. Salvo N, et al. Prophylaxis and management of acute radiation-induced skin reactions: a systematic review of the literature. Curr Oncol. 2010;17(4):94-112.

49. Brunner E, Domhof S, Langer F. Nonparametric Analysis Of Longitudinal Data In Factorial Experiments. New York, New York, USA: John Wiley and Sons; 2002.

50. Shah DA, Madden LV. Nonparametric analysis of ordinal data in designed factorial experiments. Phytopathology. 2004;94(1):33-43. 